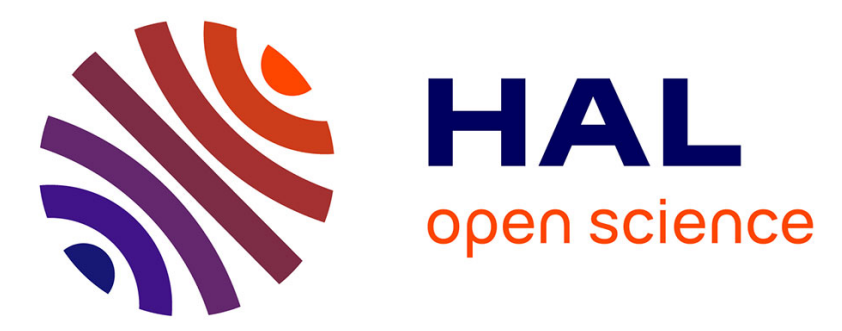

\title{
Gene transfer by histidylated lipopolyplexes: A dehydration method allowing preservation of their physicochemical parameters and transfection efficiency
}

Federico Perche, Olivier Lambert, Mathieu Berchel, Paul-Alain Jaffres, Chantal Pichon, Patrick Midoux

\section{To cite this version:}

Federico Perche, Olivier Lambert, Mathieu Berchel, Paul-Alain Jaffres, Chantal Pichon, et al.. Gene transfer by histidylated lipopolyplexes: A dehydration method allowing preservation of their physicochemical parameters and transfection efficiency. International Journal of Pharmaceutics, 2012, 423 (1), pp.144 - 150. 10.1016/j.ijpharm.2011.04.009 . hal-02995807

\section{HAL Id: hal-02995807 https://hal.science/hal-02995807}

Submitted on 3 Dec 2020

HAL is a multi-disciplinary open access archive for the deposit and dissemination of scientific research documents, whether they are published or not. The documents may come from teaching and research institutions in France or abroad, or from public or private research centers.
L'archive ouverte pluridisciplinaire $\mathbf{H A L}$, est destinée au dépôt et à la diffusion de documents scientifiques de niveau recherche, publiés ou non, émanant des établissements d'enseignement et de recherche français ou étrangers, des laboratoires publics ou privés. 
Federico Perche, Olivier Lambert, Mathieu Berchel, Paul-Alain Jaffres, Chantal Pichon, et al.. Gene transfer by histidylated lipopolyplexes: A dehydration method allowing preservation of their physicochemical parameters and transfection efficiency. 


\begin{abstract}
Background: Lipid-Polycation-DNA complexes (LPD) are promising non-viral systems for nucleic acids delivery. However, LPD are ternary complexes which are prepared extemporaneously before use, a procedure that limits their storage and handling. We have examined whether LPD dehydration would be a storage option. Results: LPD were prepared by addition of a selected liposomal formulation on preformed PEGylated histidylated polylysine / pDNA polyplexes. LPD100 with O,O-dioleyl-N-[3N-(N-methylimidazolium iodide)propylene] phosphoramidate : O,O-dioleyl-N-histamine phosphoramidate liposomes. We measured the transfection efficiency (TE) of LPD upon lyophilisation or evaporation. TE up to $60 \%$ recovery was observed after LPD100 evaporation. Moreover, TE was preserved upon one month storage. When LPD100 were prepared with dehydrated DNA/polymer complexes and fresh liposomes, TE was as efficient as with fresh LPD. Conclusion: Evaporation rather than lyophilisation was a powerful mean for storage of dehydrated LPD100 containing lipophosphoramidates.
\end{abstract}




\section{Introduction}

Gene therapy aims to use nucleic acids as medicine for curing genetic deficiencies and a large variety of acquired diseases [1]. Nucleic acids include large plasmid DNA (pDNA), small DNA as antisense oligonucleotides and RNA as ribozymes, siRNA and mRNA. pDNA encodes either proteins, oligonucleotides, ribozymes or siRNA. Their electrostatic complexes with cationic polymers or lipids are proposed as non-viral delivery systems. Accordingly, the development of lipoplexes (complexes with cationic lipids) and polyplexes (complexes with cationic polymers) has drawn much attention over last fifteen years [2, 3]. A third emerging class of Lipid-Polycation-DNA complexes termed LPD or lipopolyplexes concerns ternary complexes made with liposomes, cationic peptides or polymers and nucleic acids. LPD made with 1,2-dioleoyl-3-trimethylammonium-propane (DOTAP) : cholesterol liposomes plus protamine sulfate or dioleoyl phosphatidylethanolamine (DOPE) : cholesteryl hemisuccinate liposomes plus polylysine were the first ones developed by Huang et al., [4, 5]. LPD were also used to deliver siRNA for silencing the epidermal growth factor receptor in lung cancer cells [6]. LPD were used as adjuvant for protein-based vaccines $[7,8]$ and carrier for mRNAbased vaccines $[9,10]$. We also reported that LPD were efficient system for mRNA-based vaccine. For this purpose, mRNA encoding tumor antigen was complexed with a PEGylated histidine-rich polylysine and the resulting polyplexes were encapsulated in L-histidine-(N,Ndi-n-hexadecylamine)ethylamide : cholesterol liposomes [11]. The histidine groups of these molecules promote membrane destabilization in acidic medium allowing nucleic acid delivery in the cytosol $[12,13]$. LPD are ternary complexes that are usually prepared extemporaneously before their use, a procedure that limits storage of large quantities and would be difficult to handle by medical personnel for in vivo applications.

In the present study, we examined whether LPD dehydration would be an interesting storage option. We measured the transfection efficiency (TE) recovery of reconstituted LPD 
upon either lyophilisation or evaporation. pDNA was first condensed with PEGylated histidylated polylysine and subsequently a liposomal formulation was added to form LPD. For LPD100, O,O-dioleyl-N-(3N-(N-methylimidazolium iodide)propylene) phosphoramidate) (1) : O,O-dioleyl-N-histamine Phosphoramidate (3) liposomes were used [14, 15] (Scheme 1). The lipophosphoramidate $\mathbf{2}$ possesses an $\mathrm{N}$-methylimidazolium polar head conferring a permanent positive charge for DNA condensation. The imidazole group of the neutral colipid 3 which can acquire a cationic charge when the $\mathrm{pH}$ of the medium drops bellow $\mathrm{pH} 6$ was used to favour endosome destabilisation and pDNA delivery in the cytosol. We previously reported that lipoplexes formed with those liposomes exhibited efficient transfection [14, 15]. Lipophosphoramidates have a chemical structure which is bio-inspired from the natural phospholipids present in the cell membranes and most of these synthetic vectors proved to exhibit a moderate or low toxicity according to in vitro $[16,17]$ and in vivo $[18,19]$ transfection assays. The best preservation of LPD100 TE was obtained after evaporation rather than lyophilisation. Moreover, TE of evaporated LPD100 was preserved upon one month storage. When LPD100 were prepared with dehydrated pDNA/PEGylated histidylated polylysine complexes and fresh liposomes, TE was as efficient as with fresh ones.

\section{Materials and Methods}

\subsection{Preparation of liposomes}

Liposomes 100 (lip 100) were prepared by mixing at a molar ratio of 1:1, $1 \mathrm{~mL}$ of 5.4 mM O,O-dioleyl-N-[3N-(N-methylimidazolium iodide)propylene] Phosphoramidate (1) in ethanol and $1 \mathrm{~mL}$ of $5.4 \mathrm{mM}$ O,O-dioleyl-N-histamine Phosphoramidate (2) in ethanol [14, 15]. Ethanol solution was evaporated until formation of a film. The film was hydrated for $12 \mathrm{~h}$ at $4^{\circ} \mathrm{C}$ in $1 \mathrm{~mL}$ of $10 \mathrm{mM}$ hepes buffer, $\mathrm{pH} 7.4$, vortexed and then the suspension was sonicated for $15 \mathrm{~min}$ at $37 \mathrm{kHz}$ at $20^{\circ} \mathrm{C}$ using a Bioblock ultrasonic bath (Bioblock Scientific, Illkirch, France). 


\subsection{Plasmid DNA}

pTG11033 was a plasmid DNA of 9514 bp (kindly given by Trangène S.A., Strasbourg, France) encoding the luciferase gene of Photinus pyralis (Firefly luciferase, FLuc) under the cytomegalovirus (CMV) promoter. Supercoiled DNA was isolated from $E$. Coli DH5 $\alpha$ supercompetent bacteria (Invitrogen, Cergy Pontoise, France) by alkali lysis and purification with QIAGEN Mega Kit Endotoxin free Plasmid (Qiagen, Courtaboeuf, France).

\subsection{Polymer}

PEGylated histidylated poly-L-Lysine (PEG-HpK) was synthesized as previously described $[11,12]$.

\subsection{Lipopolyplexes}

Polyplexes (PX) were prepared at a DNA / polymer weight ratio of $1: 3(\mu \mathrm{g}: \mu \mathrm{g})$ by adding dropwise PEG-HpK (15 $\mu \mathrm{g}$ in $5 \mu \mathrm{L} 10 \mathrm{mM}$ Hepes buffer, $\mathrm{pH} 7.4)$ to DNA (5 $\mu \mathrm{g}$ in 25 $\mu \mathrm{L} 10 \mathrm{mM}$ hepes buffer, $\mathrm{pH} 7.4$ ) and mixing for $4 \mathrm{sec}$. After $30 \mathrm{~min}$ at $20^{\circ} \mathrm{C}, \mathrm{LPD}$ were formed by adding liposomes $(5 \mu \mathrm{L}$ at $5.4 \mathrm{mM} ; 10 \mu \mathrm{g})$ to $\mathrm{PX}$, a gentle mixing and letting the solution stand for $15 \mathrm{~min}$ at $20^{\circ} \mathrm{C}$. For transfection assays with fresh LPD, the solution was adjusted to $1 \mathrm{~mL}$ with serum-free medium, made $0.15 \mathrm{M} \mathrm{NaCl}$ with a $5 \mathrm{M} \mathrm{NaCl}$ solution. For LPD dehydration, the solution was adjusted to $500 \mu \mathrm{L}$ with $10 \mathrm{mM}$ Hepes buffer, pH 7.4. When indicated, the solution was adjusted to $0.15 \mathrm{M} \mathrm{NaCl}$ with a $5 \mathrm{M} \mathrm{NaCl}$ solution and / or was diluted with a 50\% saccharose solution (Sigma). For transfection assays with dehydrated LPD, the solution was reconstituted by adding $500 \mu \mathrm{L}$ of water and $500 \mu \mathrm{L}$ serum-free medium.

\subsection{Lyophilization}

PX and LPD (5 $\mu \mathrm{g}$ of plasmid DNA) at a final volume of $500 \mu \mathrm{L}$ in polypropylene cryotubes closed with a cap pitted with holes made with a $25 \mathrm{G} \times 5 / 8$ " needle (Terumo, Guyancourt, France) were frozen progressively $\left(-1^{\circ} \mathrm{C}\right.$ per min) in isopropanol $(>99.5 \%$, 
Fischer Scientific) using a Mr Frosty container (Dominique Dutscher, Brumath, France) placed in a $-70^{\circ} \mathrm{C}$ freezer during $12 \mathrm{~h}$ and freeze-dried at $-55^{\circ} \mathrm{C}, 0.05$ mbar with an Alpha 1-2 LD Plus lyophilizer (Christ, Osterode, Germany) and a vacuubrand rotary vane vacuum pump RZ 2.5 (Vacuubrand GMBH + CO KG, Wertheim, Germany) during 18h without secondary dessication.

\subsection{Evaporation}

PX and LPD dehydration was carried out at a final volume of $500 \mu \mathrm{L}$ in $1.5 \mathrm{~mL}$ polypropylene tube during $8 \mathrm{~h}$ in a Speedvac (Speedvac SC110A, Savant; Refrigerated Vapor Trap RVT 400, Savant) at $35^{\circ} \mathrm{C}, 10$ mbar. When indicated, PX and LPD were frozen progressively $\left(-1^{\circ} \mathrm{C}\right.$ per $\left.\mathrm{min}\right)$ in isopropanol before evaporation.

\subsection{DNA quantitation}

The quantity of DNA in reconstituted PX and LPD was determined by fluorescence measurement in the presence of $12 \mu \mathrm{g} / \mathrm{mL}$ of ethidium bromide (Promega, Charbonnières-lesBains , France) and $0.05 \mathrm{mg} / \mathrm{mL} 500 \mathrm{kDa}$ dextran sulfate (Sigma) in 96 wells plates. The fluorescence intensity was measured at $620 / 10 \mathrm{~nm}$ upon excitation at 531/25 nm with Victor I spectrophotometer (1420 Multilabel Counter Victor, Wallac) after 30 min of agitation on an agitating plate.

\subsection{Lipid quantitation}

The lipid concentration in reconstituted LPD was determined by fluorescence measurement in the presence of Nile Red in 96 well plates. LPD $(10 \mu \mathrm{L}$ in $70 \mu \mathrm{L}$ of $10 \mathrm{mM}$ HEPES, pH 7.4) were mixed with $20 \mu \mathrm{L}$ of a Nile Red solution ( $1 \mu \mathrm{M}$ in methanol, Sigma). The mixture was agitated for $5 \mathrm{~min}$ at room temperature on an agitating plate. The fluorescence intensity was measured at $620 / 10 \mathrm{~nm}$ upon excitation at 531/25 nm with Victor I spectrofluorophotometer.

\subsection{Size and $\zeta$ potential measurements}


The size and $\zeta$ potential of PX and LPD were measured at $7 \mu \mathrm{g} / \mathrm{mL}$ DNA by dynamic light scattering and electrophoretic mobility with ZetaSizer 3000 (Malvern Instruments, Orsay, France), respectively as previously described [12]. $20 \mu \mathrm{L}$ of liposomes or LPD containing $10 \mu \mathrm{g}$ DNA were diluted into $1.2 \mathrm{~mL}$ of $10 \mathrm{mM}$ HEPES buffer $\mathrm{pH}$ 7.4.

\subsection{Cells and cell culture}

Human embryonic kidney $293 \mathrm{~T} 7$ cells were grown at $37^{\circ} \mathrm{C}$ in a humidified atmosphere containing $5 \% \mathrm{CO}_{2}$ in MEM medium containing $10 \%$ heat inactivated fetal bovine serum (PAA Laboratories, Les Mureaux, France), $2 \mathrm{mM}$ L-glutamine (Fischer Bioblock, Illkirch, France), $100 \mathrm{U} / \mathrm{mL}$ penicillin (Fischer Bioblock) and $100 \mathrm{U} / \mathrm{mL}$ streptomycin (Fischer Bioblock) [20]. The cells were cultured in the presence of geneticin (400 mg/mL) to maintain selection of $\mathrm{T} 7$ transformants. Cells were mycoplasma-free as evidenced by bisbenzimidazole (Hoechst 33258, Molecular Probes) [21].

\subsection{Transfections}

Two days before transfection, cells were seeded in 24 well culture plates at density of $1.2 \times 10^{5}$ cells $/ \mathrm{cm}^{2}$. At the time of transfection cells were $80 \%$ confluent. Cells were then incubated for $4 \mathrm{~h}$ at $37^{\circ} \mathrm{C}$ with $0.5 \mathrm{~mL}(2.5 \mu \mathrm{g}$ DNA) transfection solution. Then, the transfection medium was removed, replaced by fresh complete culture medium and cultured for $44 \mathrm{~h}$ before measurement of the luciferase activity.

\subsection{Luciferase activity}

Luciferase activity was measured using a Lumat LB9507 luminometer (Lumat LB9507, Berthold, Wildbach, Germany) and luciferase activity (Relative Light units, RLU) was expressed per milligrams of proteins according to [22]. The amount of proteins was determined by modified bicinchoninic assay and the luciferase activity was normalized to RLU per milligram extracted protein. 


\section{Results}

\subsection{Lyophilisation of lipopolyplexes}

LPD were slowly frozen and lyophilized in Hepes buffer. The transfection of HEK293T cells with a plasmid encoding luciferase was used as read-out to test the preservation of LPD activity upon dehydration. As shown in figure 1, when LPD100 and LPD23 were freeze-dried without salt or any cryoprotectant, the luciferase activity obtained with reconstituted LPD was two orders of magnitude lower than that with fresh ones. When LPD23 were freeze-dried in the presence of $0.15 \mathrm{M} \mathrm{NaCl}$, the luciferase activity decreased also strongly (Fig. 2). This was also the case with LPD100 (not shown). This strong decrease was not associated with a lower amount of DNA and lipids in reconstituted LPD. Indeed, the quantities of DNA and lipids before lyophilisation and after rehydration of freeze-dried LPD were equal (data not shown). Table 1 shows the effect of lyophilisation on LPD size. Fresh LPD100 exhibited an average size of $118 \pm 37 \mathrm{~nm}$ in the absence of salts. At physiological salt concentration, fresh LPD100 formed aggregates of $1.7 \mu \mathrm{m}$. Upon lyophilisation in the presence of salt, the size of reconstituted LPD100 was $~ 50 \%$ smaller than fresh ones. Sugars are often employed as excipient for liposomes cryopreservation. When $2 \mathrm{mg}$ D-Mannitol were added to LPD23 solution before lyophilisation, TE of reconstituted LPD was better (15\% of that obtained with fresh LPD) than when lyophilisation was carried out in the absence of DMannitol (Fig. 2). As checked by agarose gel electrophoresis, all pDNA did not migrate in the presence of $2 \mathrm{mg}$ D-Mannitol meaning that sugar did not dissociate LPD (not shown). TE of LPD23 lyophilized in the presence of $0.15 \mathrm{M} \mathrm{NaCl}$ plus $2 \mathrm{mg}$ D-Mannitol was a little bit more (20\%) protected (Fig. 2). This was also the case for LPD100 (not shown). Note that under the latter conditions, the size of reconstituted LPD23 was small (168 nm) compared to that of LPD100 (Table 1). This small size could negatively affect their TE in vitro but it could be an advantage for transfection in vivo. 


\subsection{Evaporation of lipopolyplexes}

Whilst rarely employed, evaporation with speedvac can be used for LPD dehydration. Taking into account that freezing step causes LPD aggregation, and evaporation of unfrozen LPD produces giant liposomes [23], the evaporation of unfrozen or frozen LPD100 was tested. The evaporation of unfrozen LPD100 carried out in the presence of $0.15 \mathrm{M} \mathrm{NaCl}$ did not drastically destroy their TE (Fig. 3). The luciferase activity was about half that of fresh LPD100 for a hydration time of $1 \mathrm{~h}$ or $2 \mathrm{~h}$ but was only of one third for $5 \mathrm{~min}$ or $30 \mathrm{~min}$ hydration time. The optimal hydration time for LPD recovery was at least $1 \mathrm{~h}$. Next, we compared LPD evaporation in the presence of either salt, D-Mannitol or salt plus D-Mannitol. Evaporation of LPD100 in the presence of $0.15 \mathrm{M} \mathrm{NaCl}$ gave the best TE recovery (Fig. 4). The luciferase activity was half of that obtained with fresh LPD. For LPD23, TE recovery was $10 \%$ at the best (Fig. 4 insert). This protocol was reproducible since the TE of three different LPD100 preparations made at three different times was not statically different (Fig. 5). In contrast, TE recovery was lower when LPD were frozen before evaporation. The presence of D-Mannitol allowed reconstitution of small LPD100 (440 nm versus $1.7 \mu \mathrm{m}$ ) (Table 1). Note that TE of the latter was $10 \%$ of that obtained with the fresh ones (Fig. 4). Reconstituted frozen LPD100 evaporated in the presence of salts exhibited a smaller size than fresh ones ( 700 nm versus $1.7 \mu \mathrm{m})$ (Table 1).

\subsection{Lipopolyplexes stability}

TE of fresh LPD was not conserved after 1 month storage at $4^{\circ} \mathrm{C}$. Compared to fresh LPD100, TE were indeed 13\%. We evaluated the stability of reconstituted LPD after evaporation in the presence of $0.15 \mathrm{M} \mathrm{NaCl}$ (Fig. 6 mettre 1 mois direct). The stability was checked after 1 month in solution at $4^{\circ} \mathrm{C}$ or $-20^{\circ} \mathrm{C}$. TE of LPD was also tested after reconstitution from powder conserved 1 month at $-20^{\circ} \mathrm{C}$. A good preservation of LPD100 (60\% recovery) was observed after 1 month at $-20^{\circ} \mathrm{C}$ either as solution or powder. 


\subsection{Lipopolyplexes made with dehydrated polyplexes}

LPD were prepared with dehydrated PX (PEG-HpK polyplexes) and fresh liposomes to assume that the lost of TE of dehydrated LPD did not come from dehydration sensitivity of PX. It has been reported that lyophilisation of PX made with PEI or block copolymers did not impair TE [24-27]. As expected, TE of PEG-HpK PX was preserved after lyophilisation or evaporation (Fig. 7). TE of LPD100 made with freeze-dried PX were comparable and were only reduced by $30 \%$ to $40 \%$ compared to that of fresh LPD (Fig. 7 insert). Interestingly, TE of LPD100 reconstituted with evaporated PX was even 2-fold higher than fresh LPD100 (Fig. 8). Note that the optimal hydration time of PX was about $1 \mathrm{~h}$.

\section{Discussion}

LPD prepared by the addition of a selected liposomal formulation on preformed polyplexes (PX) are promising non-viral nucleic acids delivery systems. Here, PX were formed between a PEGylated histidylated polylysine and pDNA and LPD were prepared by the addition of liposomes 100. We previously shown that Lipoplexes with 100 exhibited powerful DNA transfection [13-15]. Usually, LPD are prepared extemporaneously before their use, a procedure that limits storage of large quantities and would be difficult to handle by medical personnel. Therefore, the preparation of efficient dehydrated LPD would be an interesting option since only hydration will be carried out before in vivo administration. For this purpose, lyophilisation has been applied to lipoplexes [28-30], polyplexes [31-35], LPD $[24,31]$ and siRNA-liposomes complexes [32, 33]. In this last case, dehydration increased the stability of siRNA-liposomes complexes by immobilization and elimination of water which is a powerful oxidant (hydrolysis) and associated water. It has been also observed that the absence of cryoprotectant produces higher particles-sizes that reduce subsequently the transfection efficiency [36]. A rapid freezing of lipoplexes in liquid nitrogen before lyophilisation has been reported to preserve their activity after rehydration $[34,37,38]$. Here, 
we decided to slowly freeze LPD according to $[39,40]$. In addition, LPD were lyophilized in Hepes buffer to prevent acidification during water elimination [24]. But, the TE recovery of our LPD dramatically decreased after lyophilisation. Dehydration submits LPD to dehydration stress, vacuum stress, temperature stress and rehydration stress. These stresses can decrease when a cryoprotectant is added to protect both sides of the liposomal membrane. For this purpose, sugars and especially disaccharides which are naturally used by many organisms to increase resistance to dehydration, are employed as excipients for cryopreservation of liposomes [41]. In prokaryotes, protection by cryoprotectants is explained by mechanisms including water replacement hypothesis [42]. The particle isolation hypothesis has been proposed to explain stability of lipid/DNA complexes after lyophilisation in the presence of sugars [43]. These sugars included inulin [44], dextran [44], dextrose, galactose, mannose [34], sucrose [38, 45], trehalose [25, 34, 40, 46], alkylglycosides [47] and D- Mannitol [48]. Unfortunately, TE of LPD100 dramatically dropped (90\% to 80\%) upon lyophilisation in the presence of $2 \mathrm{mg}$ D-Mannitol as well as in presence of salt plus $2 \mathrm{mg}$ D-Mannitol. Higher concentration of D-Mannitol should have a better effect. But, we used this sugar concentration to prevent dilutions which have to be done after reconstitution to preserve isotonicity of solutions before administration [45]. We found that lyophilisation of PX formed with PEGHpK polymer preserved their TE. When LPD were prepared with freeze-dried PX and fresh liposomes, $60 \%$ to $70 \%$ of TE was preserved for the two types of LPD meaning that dehydration of liposomes was the major hurdle. Nevertheless, PX dehydration should be a minimal option for storage.

Although lyophilisation is the main technique used for lipoplexes, PX and LPD dehydration, evaporation by speedvac is more seldom [49]. Speedvac is made of a centrifuge and a vacuum pump. The vacuum is inferior to that of a freeze-drier, so the vacuum stress is lower. Evaporation is carried out in a confined area at room temperature while lyophilisation 
is done at $-50^{\circ} \mathrm{C}$. So, speedvac evaporation could be less stressing for LPD. In contrast to lyophilisation, we observed that evaporated LPD100 retained 50\% TE upon reconstitution. LPD evaporation in the presence of $0.15 \mathrm{M} \mathrm{NaCl}$ without prior freezing and was found to be the optimal protocol for LPD100. Under this condition, the reconstitution of LPD is obtained just by adding water. Remarkably, LPD100 retained $60 \%$ transfection effciciency after one month at $-20^{\circ} \mathrm{C}$ either as solution or powder.

The mixture of the two lipophoramidates ( $\mathbf{1}$ and $\mathbf{2})$ remaining miscible upon hydration is likely in favour of the high TE recovery upon LPD100 dehydration.

LPD with a small size and a good TE recovery in vitro could be obviously used for in vivo administration. Among them, ??? of salts and fresh liposomes exhibited good recovery. Despite their low TE recovery ?? could be effective in vivo due to their smaller size.

\section{Conclusion}

The storage of LPD100 with preservation of the transfection efficiency was obtained after dehydration by evaporation.

\section{Acknowledgements}

We warmly thank Dr Arabinda Chaudhuri (Indian Institute of Chemical Technology, Hyderabad, India) for the synthesis of L-histidine-(N,N-di-n-hexadecylamine)ethylamide. Remercier Ulysse Asseline.

This work was supported by grant from Ligue Nationale contre le Cancer (Région Centre). FP was a recipient of a fellowship from Ligue Nationale contre le Cancer. 


\section{References}

[1] M.L. Edelstein, M.R. Abedi and J. Wixon, Gene therapy clinical trials worldwide to 2007--an update, J Gene Med 9 (2007) 833-842.

[2] N.S. Templeton, Nonviral delivery for genomic therapy of cancer, World J Surg 33 (2009) 685-97.

[3] M.A. Mintzer and E.E. Simanek, Nonviral vectors for gene delivery, Chem Rev 109 (2009) 259-302.

[4] X. Gao and L. Huang, Potentiation of cationic liposome-mediated gene delivery by polycations, Biochemistry 35 (1996) 1027-1036.

[5] S. Li and L. Huang, In vivo gene transfer via intravenous administration of cationic lipid-protamine-DNA (LPD) complexes, Gene Ther 4 (1997) 891-900.

[6] Y. Chen, J. Sen, S.R. Bathula, Q. Yang, R. Fittipaldi and L. Huang, Novel cationic lipid that delivers siRNA and enhances therapeutic effect in lung cancer cells, Mol Pharm 6 (2009) 696-705.

[7] J. Dileo, R. Banerjee, M. Whitmore, J.V. Nayak, L.D. Falo, Jr. and L. Huang, Lipidprotamine-DNA-mediated antigen delivery to antigen-presenting cells results in enhanced anti-tumor immune responses, Mol Ther 7 (2003) 640-8.

[8] D.P. Vangasseri, S.J. Han and L. Huang, Lipid-protamine-DNA-mediated antigen delivery, Curr Drug Deliv 2 (2005) 401-6.

[9] I. Hoerr, R. Obst, H.G. Rammensee and G. Jung, In vivo application of RNA leads to induction of specific cytotoxic T lymphocytes and antibodies, Eur J Immunol 30 (2000) $1-7$.

[10] B. Weide, C. Garbe, H.G. Rammensee and S. Pascolo, Plasmid DNA- and messenger RNA-based anti-cancer vaccination, Immunol Lett 115 (2008) 33-42. 
[11] M. Mockey, E. Bourseau, V. Chandrashekhar, A. Chaudhuri, S. Lafosse, E. Le Cam, V.F. Quesniaux, B. Ryffel, C. Pichon and P. Midoux, mRNA-based cancer vaccine: prevention of B16 melanoma progression and metastasis by systemic injection of MART1 mRNA histidylated lipopolyplexes, Cancer Gene Ther 14 (2007) 802-814.

[12] P. Midoux and M. Monsigny, Efficient gene transfer by histidylated polylysine/pDNA complexes, Bioconjug Chem 10 (1999) 406-411.

[13] V.V. Kumar, C. Pichon, M. Refregiers, B. Guerin, P. Midoux and A. Chaudhuri, Single histidine residue in head-group region is sufficient to impart remarkable gene transfection properties to cationic lipids: evidence for histidine-mediated membrane fusion at acidic pH, Gene Ther 10 (2003) 1206-1215.

[14] M. Mevel, C. Neveu, C. Goncalves, J.J. Yaouanc, C. Pichon, P.A. Jaffres and P. Midoux, Novel neutral imidazole-lipophosphoramides for transfection assays, Chem Commun (Camb) (2008) 3124-3126.

[15] M. Mevel, G. Breuzard, J.J. Yaouanc, J.C. Clement, P. Lehn, C. Pichon, P.A. Jaffres and P. Midoux, Synthesis and transfection activity of new cationic phosphoramidate lipids: high efficiency of an imidazolium derivative, Chembiochem 9 (2008) 14621471.

[16] F. Lamarche, M. Mevel, T. Montier, L. Burel-Deschamps, P. Giamarchi, R. Tripier, P. Delepine, T. Le Gall, D. Cartier, P. Lehn, P.A. Jaffres and J.C. Clement, Lipophosphoramidates as lipidic part of lipospermines for gene delivery, Bioconjug Chem 18 (2007) 1575-1582.

[17] M. Mevel, T. Montier, F. Lamarche, P. Delepine, T. Le Gall, J.J. Yaouanc, P.A. Jaffres, D. Cartier, P. Lehn and J.C. Clement, Dicationic lipophosphoramidates as DNA carriers, Bioconjug Chem 18 (2007) 1604-1611. 
[18] E. Picquet, K. Le Ny, P. Delepine, T. Montier, J.J. Yaouanc, D. Cartier, H. des Abbayes, C. Ferec and J.C. Clement, Cationic lipophosphoramidates and lipophosphoguanidines are very efficient for in vivo DNA delivery, Bioconjug Chem 16 (2005) 1051-1053.

[19] T. Le Gall, D. Loizeau, E. Picquet, N. Carmoy, J.J. Yaouanc, L. Deschamps, P. Delépine, P. Giamarchi, P.A. Jaffrès, P. Lehn and M. T, A novel cationic lipophosphoramidate with di-unsaturated lipid chains : synthesis, physico-chemical and transfection activities., J. Med. Chem. t (2010) in press.

[20] M. Brisson, W.C. Tseng, C. Almonte, S. Watkins and L. Huang, Subcellular trafficking of the cytoplasmic expression system, Hum Gene Ther 10 (1999) 26012613.

[21] T.R. Chen, In situ detection of mycoplasma contamination in cell cultures by fluorescent Hoechst 33258 stain, Exp Cell Res 104 (1977) 255-262.

[22] P. Midoux, C. Mendes, A. Legrand, J. Raimond, R. Mayer, M. Monsigny and A.C. Roche, Specific gene transfer mediated by lactosylated poly-L-lysine into hepatoma cells, Nucleic Acids Res 21 (1993) 871-878.

[23] U. Pick, Liposomes with a large trapping capacity prepared by freezing and thawing of sonicated phospholipid mixtures., Arch Biochem Biophys 212 (1981) 186-194.

[24] S. Hobel, R. Prinz, A. Malek, B. Urban-Klein, J. Sitterberg, U. Bakowsky, F. Czubayko and A. Aigner, Polyethylenimine PEI F25-LMW allows the long-term storage of frozen complexes as fully active reagents in siRNA-mediated gene targeting and DNA delivery, Eur J Pharm Biopharm 70 (2008) 29-41.

[25] C. Brus, E. Kleemann, A. Aigner, F. Czubayko and T. Kissel, Stabilization of oligonucleotide-polyethylenimine complexes by freeze-drying: physicochemical and biological characterization, J Control Release 95 (2004) 119-131. 
[26] S. Werth, B. Urban-Klein, L. Dai, S. Hobel, M. Grzelinski, U. Bakowsky, F. Czubayko and A. Aigner, A low molecular weight fraction of polyethylenimine (PEI) displays increased transfection efficiency of DNA and siRNA in fresh or lyophilized complexes, J Control Release 112 (2006) 257-270.

[27] K. Miyata, Y. Kakizawa, N. Nishiyama, Y. Yamasaki, T. Watanabe, M. Kohara and K. Kataoka, Freeze-dried formulations for in vivo gene delivery of PEGylated polyplex micelles with disulfide crosslinked cores to the liver, J Control Release 109 (2005) 15-23.

[28] C. Chen, D. Han, C. Cai and X. Tang, An overview of liposome lyophilization and its future potential, J Control Release in press (2009).

[29] J. Clement, K. Kiefer, A. Kimpfler, P. Garidel and R. Peschka-Suss, Large-scale production of lipoplexes with long shelf-life, Eur J Pharm Biopharm 59 (2005) 35-43.

[30] Z.R. Zhong, Z.R. Zhang, J. Liu, Y. Deng, H.W. Zhang, Y. Fu, Q.G. Song and Q. He, Characteristics comparison before and after lyophilization of transferrin modified Procationic-Liposome-Protamine-DNA complexes (Tf-PLPD), Arch Pharm Res 30 (2007) 102-108.

[31] X. Sun, H.W. Zhang and Z.R. Zhang, Growth inhibition of the pulmonary metastatic tumors by systemic delivery of the p27 kip1 gene using lyophilized lipid-polycationDNA complexes, J Gene Med 11 (2009) 535-544.

[32] A. Terakita, H. Matsunaga and T. Handa, The influence of water on the stability of lyophilized formulations with inositol and mannitol as excipients., Chem Pharm Bull (Tokyo) 57 (2009) 459-463.

[33] M. Grit and D.J. Crommelin, Chemical stability of liposomes: implications for their physical stability, Chem Phys Lipids 64 (1993) 3-18. 
[34] B. Li, S. Li, Y. Tan, D.B. Stolz, S.C. Watkins, L.H. Block and L. Huang, Lyophilization of cationic lipid-protamine-DNA (LPD) complexes, J Pharm Sci 89 (2000) 355-364.

[35] H.Q. Mao, K. Roy, V.L. Troung-Le, K.A. Janes, K.Y. Lin, Y. Wang, J.T. August and K.W. Leong, Chitosan-DNA nanoparticles as gene carriers: synthesis, characterization and transfection efficiency, J Control Release 70 (2001) 399-421.

[36] P. Yadava, M. Gibbs, C. Castro and J.A. Hughes, Effect of lyophilization and freezethawing on the stability of siRNA-liposome complexes, AAPS PharmSciTech 9 (2008) 335-341.

[37] T.J. Anchordoquy and G.S. Koe, Physical stability of nonviral plasmid-based therapeutics, J Pharm Sci 89 (2000) 289-296.

[38] Y. Maitani, Y. Aso, A. Yamada and S. Yoshioka, Effect of sugars on storage stability of lyophilized liposome/DNA complexes with high transfection efficiency, Int $\mathbf{J}$ Pharm 356 (2008) 69-75.

[39] J. Higgins, N.A. Hodges, C.J. Olliff and A.J. Phillips, Factors influencing cryoprotective activity and drug leakage from liposomes after freezing, J Pharm Pharmacol 38 (1986) 259-263.

[40] A.R. Mohammed, V.W. Bramwell, A.G. Coombes and Y. Perrie, Lyophilisation and sterilisation of liposomal vaccines to produce stable and sterile products, Methods 40 (2006) 30-38.

[41] L.M. Crowe, Lessons from nature: the role of sugars in anhydrobiosis, Comp Biochem Physiol A Mol Integr Physiol 131 (2002) 505-513.

[42] M. Potts, Desiccation tolerance of prokaryotes., Microbiol Rev . 58 (1994) 755-805. 
[43] S.D. Allison, M.C. Molina and T.J. Anchordoquy, Stabilization of lipid/DNA complexes during the freezing step of the lyophilization process: the particle isolation hypothesis, Biochim Biophys Acta 1468 (2000) 127-138.

[44] W.L. Hinrichs, F.A. Mancenido, N.N. Sanders, K. Braeckmans, S.C. De Smedt, J. Demeester and H.W. Frijlink, The choice of a suitable oligosaccharide to prevent aggregation of PEGylated nanoparticles during freeze thawing and freeze drying, Int $\mathbf{J}$ Pharm 311 (2006) 237-244.

[45] M.C. Molina, S.D. Allison and T.J. Anchordoquy, Maintenance of nonviral vector particle size during the freezing step of the lyophilization process is insufficient for preservation of activity: insight from other structural indicators, J Pharm Sci 90 (2001) 1445-1455.

[46] T.J. Anchordoquy, J.F. Carpenter and D.J. Kroll, Maintenance of transfection rates and physical characterization of lipid/DNA complexes after freeze-drying and rehydration, Arch Biochem Biophys 348 (1997) 199-206.

[47] G. Bendas, Synthetic glycolipids as membrane-bound cryoprotectants in the freezedrying process of liposomes., Eur J Pharm Sci 4 (1996) 211-222.

[48] R. Cortesi, E. Esposito and C. Nastruzzi, Effect of DNA complexation and freezedrying on the physicochemical characteristics of cationic liposomes, Antisense Nucleic Acid Drug Dev 10 (2000) 205-215.

[49] J. Montanari, D.I. Roncaglia, L.A. Lado, M.J. Morilla and E.L. Romero, Avoiding failed reconstitution of ultradeformable liposomes upon dehydration, Int J Pharm 372 (2009) 184-190.

[50] S. Ohtake, C. Schebor, S.P. Palecek and J.J. de Pablo, Phase behavior of freeze-dried phospholipid-cholesterol mixtures stabilized with trehalose, Biochim Biophys Acta 1713 (2005) 57-64. 
[51] J. Huang, J.T. Buboltz and G.W. Feigenson, Maximum solubility of cholesterol in phosphatidylcholine and phosphatidylethanolamine bilayers, Biochim Biophys Acta 1417 (1999) 89-100. 


\section{Figure legends}

Scheme 1: Lipid structures. 1: O,O-dioleyl-N-[3N-(N-methylimidazolium iodide)propylene] Phosphoramidate; 2: O,O-dioleyl-N-histamine Phosphoramidate.

Figure 1: Effect of LPD lyophilization on the transfection efficiency. 293T7 cells were transfected with either non lyophilised (fresh) or lyophilised (L) LPD23 (white bars) or LPD100 (black bars). The luciferase activity expressed as Relative Light Units (RLUs) per mg protein was measured after $48 \mathrm{~h}$ of culture. The values shown are averages of three independent experiments.

Figure 2: Effect of evaporation on the transfection efficiency of LPD. 293 T7 cells were transfected with unfrozen and evaporated LPD100 in the presence of $0.15 \mathrm{M} \mathrm{NaCl}$. LPD100 were resuspended in water and allowed to hydrate for different times before the transfection. The transfection efficiency is expressed as percent of that obtained with fresh LPD100. The values shown are averages of three independent experiments.

Figure 3: Effect of $\mathrm{NaCl}$ and saccharose on the transfection efficiency of evaporated LPD. 293 T7 cells were transfected with LPD100 freshly prepared or evaporated either in the presence of $0.15 \mathrm{M} \mathrm{NaCl} ; 10 \%, 20 \%$ or $30 \%$ saccharose. LPD were not frozen before evaporation. After evaporation, LPD were suspended in water and allowed to hydrate $1 \mathrm{~h}$ before the transfection. The transfection efficiency is expressed as percent of that obtained with fresh LPD100. The values shown are averages of three independent experiments.

Figure 4: Reproductibility of the transfection efficiency of LPD after evaporation. 293 T7 cells were transfected either with three different preparations of LPD evaporated in the presence of $0.15 \mathrm{M} \mathrm{NaCl}$. The transfection efficiency is expressed in Relative Light Units per $\mathrm{mg}$ of protein. Statistical analysis was performed (Student's t-test): * $\mathrm{P}=0.2, * * \mathrm{P}=0.3, * * *$ $\mathrm{P}=0.4$. The values shown are averages of three independent experiments done with evaporated LPD (white bars) and black bar represents fresh LPD. 
Figure 5: LPD stability. 293 T7 cells were transfected with fresh LPD 100, LPD 100 kept at $4^{\circ} \mathrm{C}$ or $-20^{\circ} \mathrm{C}$ after preparation during 1 month without prior dehydration, LPD100 evaporated in the presence of $0.15 \mathrm{M} \mathrm{NaCl}$. Evaporated LPD were reconstituted and kept for 30 days away from light at $4^{\circ} \mathrm{C}\left(\mathrm{S} 4^{\circ} \mathrm{C}\right)$ or at $-20^{\circ} \mathrm{C}\left(\mathrm{S}-20^{\circ} \mathrm{C}\right)$. LPD were also kept in powder at $-20^{\circ} \mathrm{C}$ for 30 days away from light and reconstituted before transfection $\left(\mathrm{P}-20^{\circ} \mathrm{C}\right)$. The transfection efficiency is expressed as percent of that obtained with fresh LPD100. The values shown are averages of three independent experiments.

Figure 6: Effect of PX dehydration on the transfection efficiency of PX and LPD. 293T7 cells were transfected with fresh PX, freeze-dried PX or evaporated PX. PX were lyophilized in the presence of $0.15 \mathrm{M} \mathrm{NaCl}$. The luciferase activity expressed as Relative Light Units (RLUs) per mg protein was measured after $48 \mathrm{~h}$ of culture.

Figure 7: Effect of PX evaporation on the transfection efficiency of LPD. 293 T7 cells were transfected with LPD100 made with unfrozen and evaporated PX. PX were evaporated in the presence of $0.15 \mathrm{M} \mathrm{NaCl}$. After evaporation, water was added and PX were hydrated for different times before LPD formation and transfection. The transfection efficiency is expressed as percent of that obtained with fresh LPD. The values shown are averages of three independent experiments.

Figure 8: Measure of pDNA by fluorescence either complexed or complexed and treated with 500 kDa dextran sulfate. White bars: without dextran sulfate, black bars: after addition of $10 \mu \mathrm{L}$ dextran sulfate. 
Table I: LPD and PX size and $\zeta$ potential values.

\begin{tabular}{|c|c|c|c|}
\hline LPD & Size (nm) & $\zeta(\mathrm{mV})$ & $\begin{array}{c}\text { DNA } \\
\text { recovery } \\
\%\end{array}$ \\
\hline \multicolumn{4}{|c|}{ fresh LDP } \\
\hline$-\mathrm{NaCl}$ & $136 \pm 5.4$ & $14.1 \pm 2.5$ & $90 \pm 1.5$ \\
\hline$+\mathrm{NaCl}$ & $1141 \pm 179$ & $0.6 \pm 8.2$ & $90 \pm 1.5$ \\
\hline $10 \%$ saccharose & $144 \pm 2.5$ & $19 \pm 2.6$ & $87 \pm 2$ \\
\hline $20 \%$ saccharose & $152.5 \pm 3$ & $20.1 \pm 3.3$ & $87.5 \pm 3$ \\
\hline $\begin{array}{l}\mathrm{NaCl} 10 \% \\
\text { saccharose }\end{array}$ & $1458 \pm 15$ & $-0.2 \pm 4.2$ & \pm \\
\hline \multicolumn{4}{|c|}{ freeze-dried LPD } \\
\hline$-\mathrm{NaCl}$ & $370 \pm 200$ & $11.5 \pm 2.8$ & $41 \pm 0.6$ \\
\hline$+\mathrm{NaCl}$ & $684 \pm 85$ & $-1.9 \pm 2.1$ & $69 \pm 7$ \\
\hline $10 \%$ saccharose & $475 \pm 60$ & $10.1 \pm 2$ & $39 \pm 0.8$ \\
\hline $20 \%$ saccharose & $702 \pm 490$ & $10.8 \pm 1.5$ & $35.5 \pm 1.6$ \\
\hline $\begin{array}{l}\mathrm{NaCl} \mathrm{10 \%} \\
\text { saccharose }\end{array}$ & $1140 \pm 142$ & $5.3 \pm 3.4$ & $53 \pm 2$ \\
\hline \multicolumn{4}{|c|}{ evaporated LPD } \\
\hline$-\mathrm{NaCl}$ & \pm & \pm & $6.5 \pm 1.7$ \\
\hline$+\mathrm{NaCl}$ & $785 \pm 140$ & $3.5 \pm 3.7$ & $42.4 \pm 2$ \\
\hline $10 \%$ saccharose & $283 \pm 5$ & $15.5 \pm 3.8$ & $24.5 \pm 0.7$ \\
\hline $20 \%$ saccharose & $180 \pm 31$ & $10.4 \pm 6.2$ & $15.3 \pm 1.5$ \\
\hline $\begin{array}{l}\mathrm{NaCl} 10 \% \\
\text { saccharose }\end{array}$ & $786 \pm 20$ & $2.7 \pm 8.6$ & $41.2 \pm 1.2$ \\
\hline \multicolumn{4}{|c|}{$\begin{array}{l}\text { LPD made with } \\
\text { dehydrated PX }\end{array}$} \\
\hline$+\mathrm{NaCl}$ & $658 \pm 42$ & \pm & \pm \\
\hline PX & Size (nm) & $\zeta(\mathrm{mV})$ & $\begin{array}{l}\text { NA recovery } \\
\%\end{array}$ \\
\hline \multicolumn{4}{|c|}{ fresh } \\
\hline$-\mathrm{NaCl}$ & $181 \pm 1$ & \pm & \pm \\
\hline$+\mathrm{NaCl}$ & $1263 \pm 14$ & \pm & \pm \\
\hline \multicolumn{4}{|c|}{ freeze-dried } \\
\hline$-\mathrm{NaCl}$ & nd & \pm & \pm \\
\hline$+\mathrm{NaCl}$ & $500 \pm 704$ & \pm & \pm \\
\hline $10 \%$ saccharose & \pm & \pm & \pm \\
\hline $20 \%$ saccharose & \pm & \pm & \pm \\
\hline $\mathrm{NaCl} 10 \%$ saccharose & \pm & \pm & \pm \\
\hline
\end{tabular}

